
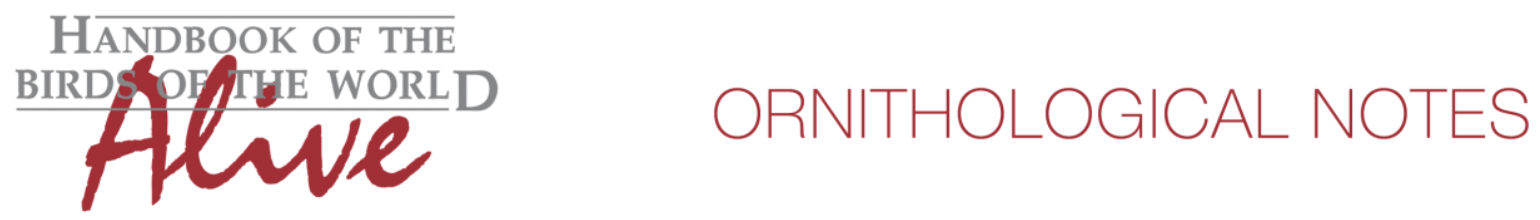

\title{
Notes on the vocalizations of Spotted Towhee (Pipilo maculatus)
}

Peter Boesman

In the following we briefly analyze and compare voice of the different races of Spotted Towhee (Pipilo maculatus). We also try to quantify the extent of any vocal differences using the criteria proposed by Tobias et al. (2010), as a support for taxonomic review.

We have made use of sound recordings available on-line from Xeno Canto (XC).

There are apparently no recordings available of race socorroensis from Socorro Island.

Song of the other races is quite variable, but typically consists of a few introductory notes followed by a trilled series of identical notes.

The main difference in song seems to be between Pacific birds (which lack introductory notes, or just utter a single note without pause linked to the trill) and the other races.

Pacific (from Oregon to Baja California coastal races): Other races:
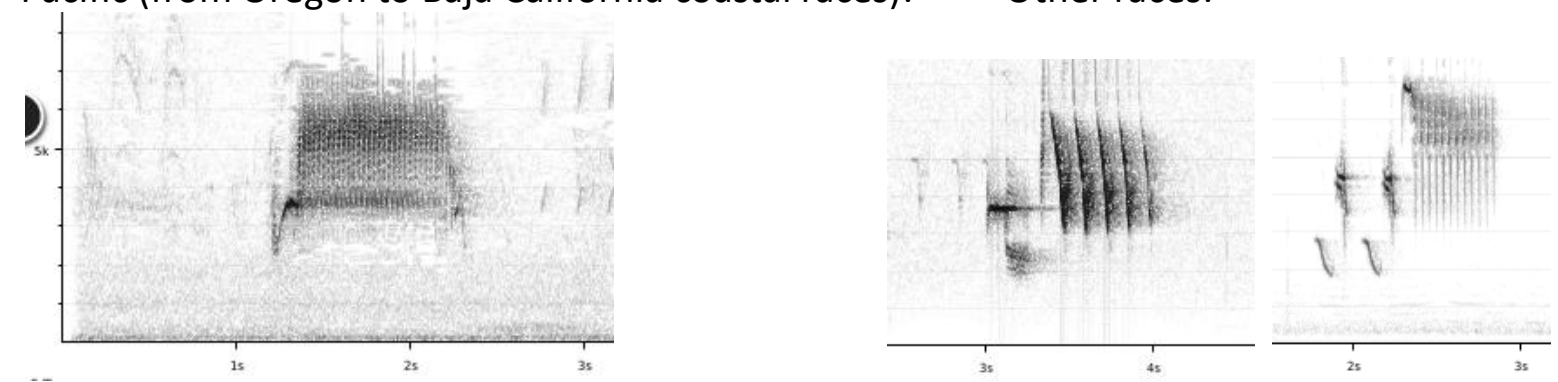

There are also vocal differences in the main call note:

Southern races (Olive-backed group) utter a piercing upslurred buzzy note not shared by other races:
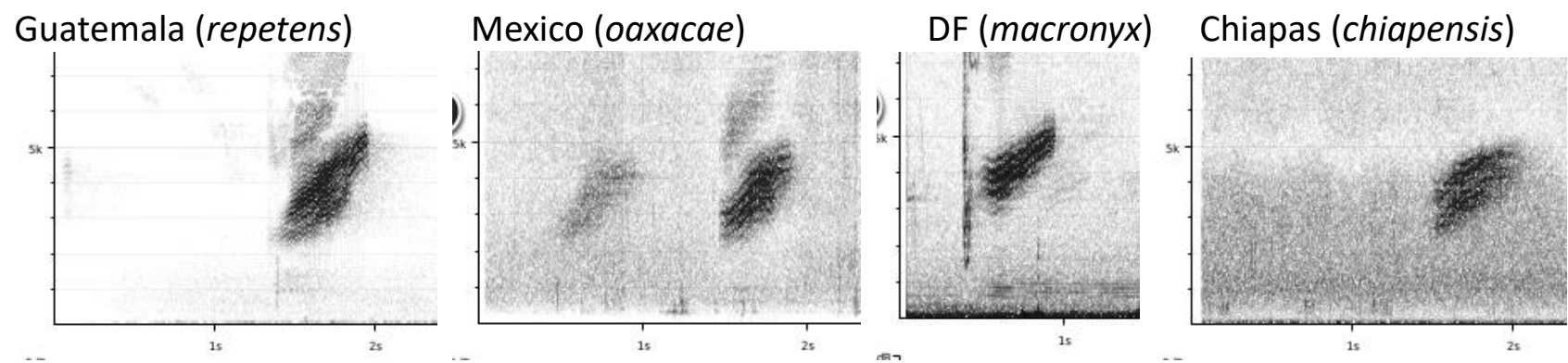

All other races utter a nasal call. In Pacific birds, call is mainly rising while for interior birds the call is usually overslurred, but there is seemingly quite some overlap.
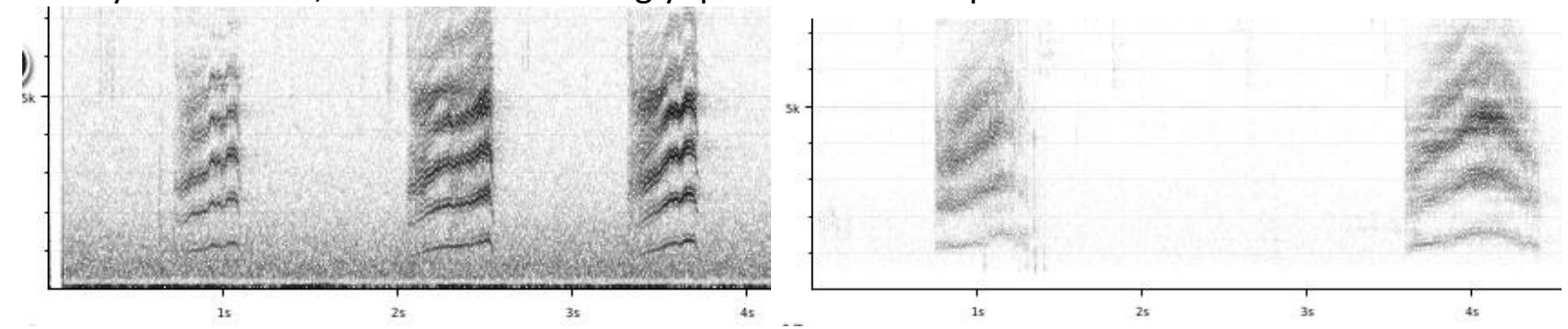

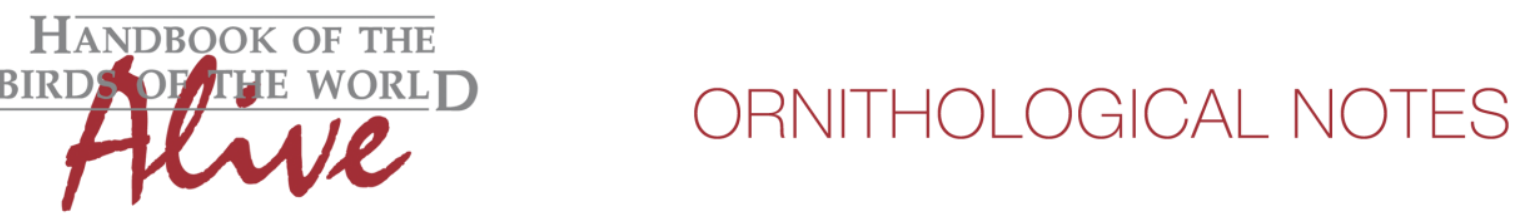

The difference in call note can be quantified and scored based on min. frequency, max. frequency of the base harmonic, freq. range (bandwidth) of the base harmonic (or end. freq. minus start freq.) or number of harmonics. Although this is not the primary vocalization, scoring would lead to a vocal score of about 4.

Note that vocal difference vs Eastern Towhee $P$. erythrophthalmus is also mainly the call rather than song. Example of such calls:
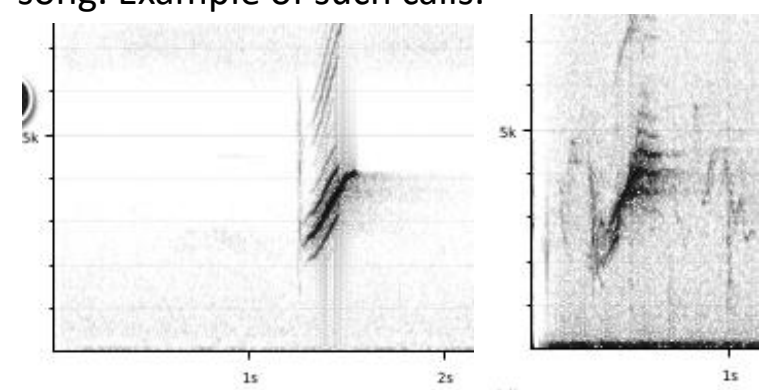

These are clearly closer to the Olive-backed group.

This note was finalized on 25th May 2016, using sound recordings available on-line at that moment. We would like to thank in particular the many sound recordists who placed their recordings for this species on XC.

\section{References}

Tobias, J.A., Seddon, N., Spottiswoode, C.N., Pilgrim, J.D., Fishpool, L.D.C. \& Collar, N.J. (2010). Quantitative criteria for species delimitation. Ibis 152(4): 724-746.

\section{Recommended citation}

Boesman, P. (2016). Notes on the vocalizations of Spotted Towhee (Pipilo maculatus). HBW Alive Ornithological Note 363. In: Handbook of the Birds of the World Alive. Lynx Edicions, Barcelona. (retrieved from http://www.hbw.com/node/1252907 on 2 November 2016). 